\title{
The Effect Of Visual Warning On Cigarette Packs of Intention to Quit Smoking At Online Taxibike Rider In Banda Aceh
}

\author{
Rahmi Izzati*, Said Usman, Irwan Saputra, Marthoenis, Martunis \\ Department of Public Health, Faculty of Medicine Universitas Syiah Kuala, Indonesia \\ *rahmi.mkm2020@gmail.com
}

\begin{abstract}
According to data of World Health Organization (WHO), Indonesia was the third largest country with the biggest number of smokers in the world after China and India. Riset Kesehatan Dasar (Basic Health Research) 2018 stated the number of smokers in Indonesia was still very high, that was 33 percent (the third highest in the world) or 1 in 3 Indonesians smoked, with male smoker by 63 percent or 2 in 3 Indonesian men smoked. Government set smoking hazards warning and included health warnings and informations on cigarette packs, however these did not show a significant effect for smokers. Banda Aceh city has motorcycle taxis company (Online taxibike Rider) and facts in the field showed that not a few who set aside money they obtained to buy cigarette. This study used analytics survey with cross sectional approach. Research population were online taxibike Rider by sampling using purposive sampling method so that 155 samples were obtained. There were a significant effect between image illustration and intention to quit smoking $\mathrm{OR}=3.01 \mathrm{P}=0.008$, between typography and intention to quit smoking $\mathrm{OR}=3.62 \mathrm{P}=0.003$, between the color and intention to quit smoking $\mathrm{OR}=3.37 \mathrm{P}=0.04$, between layout and intention to quit smoking $\mathrm{OR}=3.48 \mathrm{P}=0.002$. The variable that the most influence the intention to quit smoking on taxibike Rider was visual warnings in color forms $\mathrm{OR}=2.29$ $\mathrm{P}=0.010$. The visual warnings on cigarette packs can affect intention to quit smoking on online taxibike Rider. The result of the study presented that visual warning signs on cigarette packs could rise the intention to quit smoking on online taxibike Rider.
\end{abstract}

Keywords : Visual warning, Intention to Quit Smoking, Online Taxibike Rider

Received August 1, 2020; Revised August 24, 2020; Accepted September 5, 2020 


\section{STRADA Jurnal Ilmiah Kesehatan}

DOI: $10.30994 /$ sjik.v9i2.388

ISSN: 2252-3847 (print); 2614-350X (online)

Vol.9 No.2 November 2020 Page.820-825

\section{BACKGROUND}

Smoking is one of those habits that cause public health problem. In daily life, people often smoke everywhere, both in public places and private residences. Smoking is one of the biggest causes of death in the community. Smoking habits will cause many problems, not only for the smoker (active smoker), but also impact on the person who inhale the smoke (passive smoker). Indonesia is a country with the highest per capita cigarette consumption rate in ASEAN. Data from tobaccoaltlas.org showed that cigarette consumptions of Indonesian people age 15 years and over in 2014 reached 1,322.3 cigarettes per capita per year. In second place was Philippine with consumptions 1,291.08 cigarettes per capita per year. In third place was Vietnam with consumption 1,215.3 cigarettes per year. Data from Riset Kesehatan Masyarakat (Basic Health Researches or RISKESDAS) in 2018 stated that the prevalence of smoking in age 15 years and over as much as $28.8 \%$. However, what more concerning was the prevalence of smoking in adolescents since 2013 was recorded as much as $7.2 \%$ and increased to $8.8 \%$. The percentage jumped to $9.1 \%$ on Riskesdas 2018 .

Government regulated the dangers of smoking warnings and included health warnings and informations on cigarette packs, however it did not show a significant impact on the smokers. The government issued pictorial health warnings on cigarette packs in accordance with Government Regulations PP 109 of 2012 with five pictures accompanied by a warning with different writings according to the picture. The description about inclusion of pictorials and writings health warning were explained on Health Minister Regulation no 28 of 2013 about The Inclusion of Health Warning and Health Information on Tobacco Product Packaging. The regulation that was issued by health minister was applied for all cigarette companies starting on $24^{\text {th }}$ June of 2014 and hopefully it would make people aware about the dangers of smoking.

Banda Aceh is one of city which has an increasingly dense population. With so many people both from Aceh and outside Aceh who settled to look for work to meet the costs of their daily needs, it did not rule out that the part of community in Banda Aceh had a risk of smoking habits. Smoker prevalence of smokers in Province Aceh for residents aged $\geq 10$ years according to smoking habits, namely daily smoker as much as $40 \%$. Smoking habits had a major impact on humans, which smokers in general started smoking as adolescents. The impact of smoking would be felt after 10-20 years of consumption. According to interview results with ten online motorcycle taxi drivers who were waiting for orders and seen smoking at motorcycle taxi bases, they said that smoking was a habit that are not good for health. They also knew the impact that was caused by smoking both in terms of health and economy. When the researchers asked about their purposes of smoking, some of them argued that smoking was an entertainment to fill their spare time when waiting for an taxi order, some even answered that smoking became their daily habits and they could not even quit. Based on these, the researchers were interested to see the influence of visual warning on cigarette packs on the intention to quit smoking on online motorcycle taxi drivers in Banda Aceh.

\section{MATERIALS AND METHOD \\ Method}

This research used an analytic survey with cross sectional approach that the independent and dependent variables of the research were measured simultaneously in the same period of time. This research was done at online motorcycle taxi bases. It was done at $2^{\text {nd }}-8^{\text {th }}$ July of 2020 . 


\section{STRADA Jurnal Ilmiah Kesehatan}

DOI: $10.30994 /$ sjik.v9i2.388

ISSN: 2252-3847 (print); 2614-350X (online)

Vol.9 No.2 November 2020 Page.820-825

\section{Population}

The population on this research were the informal workers (online motorcycle taxis) who were waiting for orders from the service users in the bases of online motorcycle taxi drivers.

\section{Sampling Technique}

Technique and sampling in this research was using purposive sampling method, which each location would be taken around 10-15 people with a total sample of 155 people.

\section{RESULT}

This research was done at $2^{\text {nd }}-8^{\text {th }}$ July of 2020 at online motorcycle taxi drivers bases in Banda Aceh.

Table 1. The intention to quit smoking

\begin{tabular}{clccc}
\hline No. & \multicolumn{2}{l}{ The intention to quit smoking } & $(\mathbf{f})$ & $(\boldsymbol{\%})$ \\
\hline 1. & No & & 87 & 56.1 \\
2. & yes & & 68 & 43.9 \\
& & Total & 155 & 100 \\
\hline
\end{tabular}

Based on table 1, it shows that the proportion of the intention to quit smoking by online motorcycle taxi drivers was that they had no intention, as much as 87 respondents $(56.1 \%)$

Table 2. Number of cigarettes Smoked per day

\begin{tabular}{clcc}
\hline No. & Number of cigarettes & (f) & $(\boldsymbol{\%})$ \\
\hline 1. & 1-5 cigarettes & 27 & 17.4 \\
2. & 6-15 cigarettes & 82 & 52.9 \\
3. & More than 15 cigarettes & 46 & 29.7 \\
& Total & 155 & 100 \\
\hline
\end{tabular}

Based on table 2, it shows that the proportion of the number of cigarettes smoked per day by online motorcycle taxi drivers was mostly 6-15 cigarettes per day was $52.9 \%$.

Table 3. The effect of image illustration on the intentions to quit smoking.

\begin{tabular}{|c|c|c|c|c|c|c|c|c|c|}
\hline \multirow{3}{*}{$\begin{array}{l}\text { Illustrated } \\
\text { image }\end{array}$} & \multicolumn{4}{|c|}{$\begin{array}{l}\text { The intention to quit } \\
\text { smoking }\end{array}$} & \multirow{2}{*}{\multicolumn{2}{|c|}{ Total }} & \multirow{3}{*}{$\begin{array}{c}\text { OR } \\
(95 \% \\
\text { CI })\end{array}$} & \multirow[t]{3}{*}{$\alpha$} & \multirow{3}{*}{$\begin{array}{c}\mathrm{P} . \\
\text { value }\end{array}$} \\
\hline & \multicolumn{2}{|c|}{ No } & \multicolumn{2}{|c|}{ Yes } & & & & & \\
\hline & $\mathrm{F}$ & $\%$ & $\mathrm{~F}$ & $\%$ & $\mathrm{~F}$ & $\%$ & & & \\
\hline $\begin{array}{l}\text { have } \\
\text { effect }\end{array}$ & 32 & $\begin{array}{c}74 . \\
4\end{array}$ & 11 & 25.6 & 43 & 100 & $\begin{array}{l}3.0(1.3 \\
-6.5)\end{array}$ & 0.05 & 0.008 \\
\hline $\begin{array}{l}\text { Have } \\
\text { effect }\end{array}$ & 55 & $\begin{array}{c}49 . \\
1\end{array}$ & 57 & 50.9 & 112 & 100 & & & \\
\hline Total & 87 & $\begin{array}{c}56 . \\
1\end{array}$ & 68 & 43.9 & 155 & 100 & & & \\
\hline
\end{tabular}

Based on table 3 , it showed that there were 43 respondents who stated that illustrated images did not affect the intention to quit smoking, there were 32 respondents $(74.4 \%)$ who had no the intention to quit smoking, and 112 respondents who stated that illustrated images affected the intention to quit smoking, there were 57 respondents $(50.9 \%)$ who had the intention to quit smoking. 


\section{STRADA Jurnal Ilmiah Kesehatan}

DOI: $10.30994 /$ sjik.v9i2.388

ISSN: 2252-3847 (print); 2614-350X (online)

Vol.9 No.2 November 2020 Page.820-825

Statistical test result obtained $\mathrm{P}$ value $=0.008(\mathrm{P}$. value $<\alpha=0,05)$ then Ha accepted, meaning there was a significant effect of visual warning in the form of illustrated images on the intention to quit smoking on online motorcycle taxi drivers in Banda Aceh.

The result of Chi Square test obtained value of Odds Ratio 3.0, meaning visual warning in form of illustrated images had a chance to effect the intention to quit smoking was 3.0 times compared to respondents who had an illustrated images assessment had no effect.

Table 4. The influence of typography on the intention to quit smoking

\begin{tabular}{|c|c|c|c|c|c|c|c|c|c|}
\hline \multirow[t]{3}{*}{ Typography } & \multicolumn{4}{|c|}{$\begin{array}{c}\text { The intention to quit } \\
\text { smoking }\end{array}$} & \multirow{2}{*}{\multicolumn{2}{|c|}{ Total }} & \multirow{3}{*}{$\begin{array}{c}\text { OR } \\
(95 \% \\
\text { CI })\end{array}$} & \multirow[t]{3}{*}{$\alpha$} & \multirow[t]{3}{*}{ P. value } \\
\hline & \multicolumn{2}{|c|}{ No } & \multicolumn{2}{|c|}{ Yes } & & & & & \\
\hline & $\mathrm{F}$ & $\%$ & $\mathrm{~F}$ & $\%$ & $\mathrm{~F}$ & $\%$ & & & \\
\hline $\begin{array}{l}\text { Have } \\
\text { effect }\end{array}$ & 31 & 77.5 & 9 & 22.5 & 40 & $\begin{array}{c}10 \\
0\end{array}$ & $\begin{array}{l}3.6 \\
(1.5-\end{array}$ & 0.05 & 0.003 \\
\hline $\begin{array}{l}\text { Have } \\
\text { effect }\end{array}$ & 56 & 48.7 & 59 & 51,3 & $\begin{array}{c}11 \\
5\end{array}$ & $\begin{array}{c}10 \\
0\end{array}$ & 8.3) & & \\
\hline Total & 87 & 56.1 & 68 & 43.9 & $\begin{array}{c}15 \\
5\end{array}$ & $\begin{array}{c}10 \\
0\end{array}$ & & & \\
\hline
\end{tabular}

Based on table 4, statistics test result obtained $\mathrm{P}$ value 0.003 ( $\mathrm{P}$ value $<$ value $\alpha=0,05$ ) so $\mathrm{Ha}$ accepted, meaning there was a significant effect of visual warnings in form of typography on the intention to quit smoking on online motorcycle taxi drivers in Banda Aceh.

The result of Chi-Square test obtained value of Odds Ratio 3.6, meaning visual warning in form of typography had a chance to affect the intention to quit smoking was 3.6 times compared to respondents who had typography assessments had no effect.

Table 5. the effect of color on the intention to quit smoking

\begin{tabular}{|c|c|c|c|c|c|c|c|c|c|c|}
\hline \multirow[t]{3}{*}{ Color } & & \multicolumn{4}{|c|}{$\begin{array}{l}\text { The intention to quit } \\
\text { smoking }\end{array}$} & \multirow{2}{*}{\multicolumn{2}{|c|}{ Total }} & \multirow[t]{2}{*}{$\begin{array}{c}\text { OR } \\
(95 \% \mathrm{CI})\end{array}$} & \multirow[t]{3}{*}{$\alpha$} & \multirow{3}{*}{$\begin{array}{l}\mathrm{P} . \\
\text { value }\end{array}$} \\
\hline & & \multicolumn{2}{|c|}{ No } & \multicolumn{2}{|c|}{ Yes } & & & & & \\
\hline & & $\mathrm{F}$ & $\%$ & $\mathrm{~F}$ & $\%$ & $\mathrm{~F}$ & $\%$ & & & \\
\hline $\begin{array}{l}\text { Have } \\
\text { effect }\end{array}$ & no & 32 & 76.2 & 10 & 23.8 & 42 & $\begin{array}{c}10 \\
0\end{array}$ & $\begin{array}{l}3.375 \\
7.51)\end{array}$ & 0.05 & 0.004 \\
\hline $\begin{array}{l}\text { Have } \\
\text { effect }\end{array}$ & an & 55 & 48.7 & 58 & 51.3 & 113 & $\begin{array}{c}10 \\
0\end{array}$ & & & \\
\hline Total & & 87 & 56.1 & 68 & 43.9 & 155 & $\begin{array}{c}10 \\
0\end{array}$ & & & \\
\hline
\end{tabular}

Source, primary data 2020

From table 5, 42 respondents who stated color did not affect the intention to quit smoking, there were 32 respondents $(76.2 \%)$ had no the intention to quit smoking, and from 113 respondents who stated color effected the intention to quit smoking, there were 58 respondents $(51.3 \%)$ had intention to quit smoking.

Statistics test result obtained $\mathrm{P}$ value $=0.004$ ( $\mathrm{P}$ value $<\alpha=0,05)$ so Ha accepted, meaning there was a significant effect of visual warning in form of color on the intention to quit smoking by online taxibike rider in Banda Aceh. 


\section{STRADA Jurnal Ilmiah Kesehatan}

DOI: $10.30994 /$ sjik.v9i2.388

ISSN: 2252-3847 (print); 2614-350X (online)

Vol.9 No.2 November 2020 Page.820-825

The result of Chi-Square test value obtained value of Odds ratio 3.37, meaning visual warning in form of color had an opportunity to influence the intention to quit smoking was 3.37 times compared to respondents who had color assessments had no effect.

Table 6. the influence of layout on the intention to quit smoking

\begin{tabular}{|c|c|c|c|c|c|c|c|c|c|c|}
\hline \multirow[t]{3}{*}{ Layout } & & \multicolumn{4}{|c|}{$\begin{array}{l}\text { The intention to quit } \\
\text { smoking }\end{array}$} & \multirow{2}{*}{\multicolumn{2}{|c|}{ Total }} & \multirow[t]{3}{*}{$\begin{array}{l}\text { OR } \\
(95 \% \mathrm{CI})\end{array}$} & \multirow[t]{3}{*}{$\alpha$} & \multirow{3}{*}{$\begin{array}{c}\mathrm{P} . \\
\text { value }\end{array}$} \\
\hline & & \multicolumn{2}{|c|}{ No } & \multicolumn{2}{|c|}{ Yes } & & & & & \\
\hline & & $\mathrm{F}$ & $\%$ & $\mathrm{~F}$ & $\%$ & $\mathrm{~F}$ & $\%$ & & & \\
\hline Have & no & & 76,1 & 11 & 23,9 & 46 & 100 & $3,488(1,60-$ & 0,05 & 0,002 \\
\hline $\begin{array}{l}\text { Have } \\
\text { effect }\end{array}$ & an & 52 & 47,7 & 57 & 52.3 & 109 & 100 & 7,56)) & & \\
\hline Total & & 87 & 56,1 & 68 & 43,9 & 155 & 100 & & & \\
\hline
\end{tabular}

From table 6, it displays 46 respondents who stated layout had no effect on the intention to quit smoking, there were 35 respondents $(76.1 \%)$ had no intention to quit smoking, and from 109 respondents who stated layout had effect on the intention to quit smoking, there were 57 respondents $(52.3 \%)$ had an intention to quit smoking.

Statistics test result obtained P value $=0.002$ ( $\mathrm{p}$ value $<$ value of $\alpha=0,05)$ so Ha accepted, meaning there was a significant effect of visual warning in form of layout on the intention of quit smoking on online motorcycle taxi drivers in Banda Aceh.

The result of Chi-Square obtained value of Odd Ratio 3.48, meaning the visual warnings in form of layout had an opportunity to affect the intention to quit smoking was 3.48 times compared to respondents who had layout assessments had no effect.

Table 7. Dominant factors which influence the intention to quit smoking

\begin{tabular}{cccc}
\hline Variable & Odds Ratio & CI 95\% & P-Value \\
\hline Color & 2.92 & $1.29-6.63$ & 0.010 \\
Illustrated images & 2.57 & $1.15-5.73$ & 0.021 \\
\hline
\end{tabular}

Based on table 7, there were two variables that affect significantly on the intention to quit smoking by online taxibike rider that were color variable and illustrated images variable. Based on statistics test result, color variable was the most effect variable on the intention to quit smoking by online motorcycle taxi drivers with $\mathrm{P}$ value $=0.01$ and $\mathrm{OR}=2.92$, which means visual warning in form of color which stated by respondents had a tendency of 2.92 times chance on the intention to quit smoking compared to respondents who stated color had no effect.

\section{DISCUSSION}

The result of research shows that there was a significant effect on visual warnings on cigarette packs consisting of illustrated images, typography, color, and layout on the intention to quit smoking on online motorcycle taxi drivers in Banda Aceh. The result was in line with the research that was done by (Siti Nurfadillah, 2015), with title the effect of smoking health warning labels on smoking habit in active smoking students in UIN Syarif Hidayatullah Jakarta with intensity looking at cigarette labels more than five times in a month, obtained that it effected on smoking habit was $30.2 \%$ and did not affect the smoking habit was $68.8 \%$. 


\section{STRADA Jurnal Ilmiah Kesehatan}

DOI: $10.30994 /$ sjik.v9i2.388

ISSN: 2252-3847 (print); 2614-350X (online)

Vol.9 No.2 November 2020 Page.820-825

Surveys and experimental researches in other countries reported that text warnings was more effected than illustrated warnings only to inform the smokes about smoking risks and smoking cessation. Elliot and Shanahan's research (2008) on his research evaluation also stated that health warning that using text was considered had bigger impact than image warnings only.

This research supported research that was done by Bansal-Travers, Hammond, Smith, \& Cummings (2011), which was done in New York, USA on 397 respondents, reported that color and description product associated with false belief about risks. Plain packaging decreased many misperceptions that were wrong about the risks through the packaging feature. Article 11 WHO FCTC explained that the use of color as the opposite of black and white affect the overall information as a whole pictorial elements of health warnings and messages. Therefore, it was strongly recommended that all parties used color rather than black and white. Contrast color for background texts in order to increase warnings can maximize health warning text based elements.

Southeast Asia Tobacco Control Alliance (SEATCA 2008) also reported that several researches which was done di southeast Asia explained that some respondents in Laos stated warning size had to large and included the images. Half of respondents who majority were a smoker recommended pictorial image warnings must cover $50 \%$ to $100 \%$ of main display area. Reports in Vietnam stated that respondents preferred pictorial health warnings covered more than $50 \%$ of main display. Majority respondents in Cambodia $(90.5 \%)$ stated that the warning must larger and more prominent shown at the front covers $50 \%$ or more packaging. While in Indonesia stated that $78 \%$ respondents preferred warnings that covered about $50 \%$ of cigarette packaging.

\section{CONCLUSION}

There were a significant effect between illustrated images, typography, color, and layout on cigarette packs with the intention to quit smoking in online motorcycle taxi drivers in Banda Aceh. Suggestions from the Aceh Government and the Aceh Provincial Health Office need regular quarterly evaluations of the implementation of the Smoke Free Area policy in public places. It is necessary to immediately stipulate and ratify the Qanun for Smoking Free Areas in Aceh Province, in order to reduce the number of smokers in general areas in the Aceh Province

\section{REFFERENCE}

Hammond, D., (2009). Tobacco labeling \& packaging toolkit: a guide to FCTC article 11. Waterloo, On: Tobacco Labeling Resource Centre.

Kementrian Kesehatan Indonesia., (2013). Pencantuman peringatan kesehatan dan informasi kesehatan pada kemasan produk tembakau. Peraturan Menteri Kesehatan Republik Indonesia Nomor 28 Tahun 2013.

Nurfadilah S., Pengaruh Label Peringatan Kesehatan Merokok dengan Perilaku Merokok Aktif di UIN Syarif Hidayatullah, Jakarta, 2015

Riset Kesehatan Dasar., (2018). Jakarta: Badan Penelitian dan Pengembangan Kesehatan, Departemen Kesehatan, Republik Indonesia.

Southest Asia Tobacco Control Alliance (SEATCA 2008). Regional efficacy testing graphic health warning in Asean Countries of Cambodia, Indonesia, Lao PDR, Malaysia, Philippines, Thailand, and Vietnam

WHO. World Health Statistics 2015: World Health Organization; 2015. 